\title{
Civilisations
}

Revue internationale d'anthropologie et de sciences

humaines

42-2 | 1993

enQuete d'identité

\section{The construction of jewish identity in Hungary in the 1980 s}

\author{
Dr. Ferenc Eros
}

\section{OpenEdition \\ Journals}

Édition électronique

URL : http://journals.openedition.org/civilisations/2325

DOI : 10.4000/civilisations. 2325

ISSN : 2032-0442

\section{Éditeur}

Institut de sociologie de l'Université Libre de Bruxelles

\section{Édition imprimée}

Date de publication : 1 décembre 1993

Pagination : 141-150

ISBN : 2-87263-108-9

ISSN : 0009-8140

Référence électronique

Dr. Ferenc Eros, «The construction of jewish identity in Hungary in the 1980s », Civilisations [En ligne] 42-2 | 1993, mis en ligne le 01 décembre 1996, consulté le 02 mai 2019. URL : http://

journals.openedition.org/civilisations/2325; DOI : 10.4000/civilisations.2325

Ce document a été généré automatiquement le 2 mai 2019.

(c) Tous droits réservés 


\title{
The construction of jewish identity in Hungary in the $1980 \mathrm{~s}^{1}$
}

\author{
Dr. Ferenc Eros
}

1 Jewish identity in the diaspora has always had its problematic sides, particularly in the last hundred years. As a consequence of secularization. the erosion or dissolution of traditional communities. rapid assimilation processes etc. Jewish identity became more problematic. its borders and definitions became more vague, doubtful or flexible. Definitions of "being a Jew" were relativized; they became various points on a sc ale which may range from belonging to a ritual community. to a distinct ethnie, religious and/ or linguistic group, through belonging to more or less welldefined subcultures and/ or traditions, up to the point where no Jewish identity exists at all.

2 Nevertheless, before the rise of totalitarian regimes, it was, at least theoretically, the decision of the individual person where he or she wanted to belong or what form of Jewish identity among the existing alternatives he or she would prefer to main tain, cultivate and pass on to the next generations. The assimilation process of the Hungarian Jewry, however rapid and massive it was from the second half of the nineteenth century on, did leave open sorne room for individual choice. One could have been perfectly "assimilated" according to most of the sociological parameters (indu ding name choice, education, or even marriage and religion); this fact, however, did not necessarily prevents the individual from maintaining spiritual, social or solidarity ties with other people perceived as Jewish. Morevor, Jews could belong to more then one community at the same time: they could be members of the Jewish community and, simultaneously, full-right members of the political nation they were citizens of.

3 It was the political antisemitism of the thirties and forties, raised to the level of official state policy, which first deprived them of their Hungarian identity and then imposed on them an extemally and forcefully defmed Jewish identity, based on race and blood. Holocaust, the annihilation of the Jews, was, in this sense, the logical consequence of a policy which denies and forcefully determines identity as an act of state. Holocaust was the final de privation of human identity, and, for the majority, of life. 
For the survivors of the Holocaust and their offsprings Communism, the new totalitarian system emerging after 1945, promised a new society where no discrimination, whether racial, ethnie, or national, could exist. The universalistic daims of Communist ideology were particularly appealing for a significant portion of Jews, because this ideology and this form of social organisation were perceived as a guarentee that at least one category of identity -human identity as such- cannot be denied to Jews as well as to other groups. In addition, the new regime offered special benefits for Jews as being practically the only major group in the country which was in no way affected or infected by the right wing or fascist movements and ideologies of the recent pasto The priee for all this was, however, very serious: those who decided to find their place in the new regime had to give up the reminants of their Jewish identity -at least in all areas of public manifestation. Jewish identity was marginalized again -and this marginalization was concomitant with the repression of the memory of Holocaust.

Then, the crucial question is: what happened to Jewish identity in the intersection of repression and marginalization, how it was further distorted under the superimposing effects of Holocaust and Communism?

6 Forty years after the Holocaust, in the early 1980s, Andnis Kovâcs, Katalin Lévai and I started a research project on Hungarian Jewish identity ${ }^{2}$. The project was basically a collection of detailed life histories of people belonging to the "second generation", i.e., of those whose parents survived the Holocaust. Most of our respondents were born in the period between 1945-1960. I have to admit that -beyond our "scientific" interest- there was another, underlying motive in making this project: to fulfill a mission, to discover at least something about the generation which seemed then to have disappeared in the wave of assimilation and whose members seemed to remain completely alone with their problems. Beyond "science" and "mission", there was, at least for me personally, a third motive: to find my own identity. We found the signs of identity crisis and the search for identity in both what the respondents told us and what they did not talk about; the speech and the silence, the urge to talk as well as the fears and anxieties associated with raising this issues - all this remïnded me of my own ambivalent feelings. For many of us, the interview situation was the first step in a communicative experience the interviews convinced both interviewer and interviewee that they were not quite alone in their ambivalences, in their dubitous, vague feelings and knowledge about being Jewish - that there must be, however latently and marginally, a community or a group to which they could relate their own personal feelings.

7 From the "scientific" point of view, we were interested primarily in the specifie features of identity formation, socialization and personality development among the "second generation" in postwar Hungary. In the course of this research we collected about 150 indepth interviews, which are still -due to financial, technical and other difficulties- only partly worked up. However, due to the sudden and in many ways unexpected political and social changes in the late eighties, our inteview materials became, in a way, "obsolete"; they belong now, so to speak, to the historical past. As is well known, in the last two or three years, the public representation of Jewish identity changed dramatically. Nowadays, Jewish identity or at least various elements of a Jewish identity can be openly manifested, there are newly founded organizations, cultural and educational facilites, there is a revival of or at least a growing interest in the traditions, the religious and cultural values etc. On the other hand, as is also weIl known, there is a growing or at least more visible tendency towards antisemitism in the country. It was instructive, for example, to observe 
during the 1990 election campaign that the now ruling party, the Christian Democratie and nationally oriented Hungarian Democratie Forum, while it made certain reconciliatory gestures toward the Jewish community, the party has not distanced itself as a whole from the almost openly antisemitic currents inside its ranks. This trend continues in our days and the new political situation creates new types of conflicts for Jews as weIl as for non-Jews in Hungary.

When we conducted our interviews in the eighties, the hegemony of the communist party state was still -at least seemingly- unbroken. To be sure, the questions were the same as today: who is a Jew, what is a Jew, what does it mean to be Jewish in Hungary, what are the basic factual and ideological elements of a Jewish identity etc. However, these questions were pronounced only in the privacy of the interview situation. Let us now examine in some details the construction of Jewish identity as seen through the se interviews.

\section{The Holocaust and jewish identity}

9 Our research project originated, historically, as a sociopsychological study of the postHolocaust generation. It was no coincidence that the Holocaust was central in our questions. First, we felt that it was precisely the issue which was forcefully (and also voluntarily) exduded from public discussion; second, we learnt, in that time, of the dinical psychological and psychoanalytical studies dealing with the traumatizing effects of the Holocaust and the (unconscious) transmission of the trauma to the next generation. These studies had been made in Western countries and in Israel, but similar work was started also in Hungary in the early eighties, almost in parallel with our interviews, by Dr. Teréz Virag'. Her work also revealed the so-called "survivor's syndrome" and the "second generation syndrome", which are so well known in the psychoanalytic literature on Holocaust ${ }^{4}$. Our interviews were, of course, not psychoanalytical, though we endeavoured to utilize some principles and methods of analytical interview technique. When talking about their parents, many respondents described them as completely depressed, emotionally emptied persons who were -or still are- unable to talk about or cope with the memory of the extreme situations they survived -including the death of their close kin. When talking about themselves, our interwievees related their fears, anxieties, persecution dreams and daydreams, which haunt this generation. Since, however, we did not endeavour to write up individual case studies, it was not our aim to decide whether these people were really "sick" or not. What was most striking for us from the "pathological" point of view, was what psychoanalysts call disturbances of "object relations", ambivalent relations or sometimes an almost complete incapacity of true relatedness with the relevant "objects" of the external world, with parents, partners etc.

A similar ambivalence was characteristic of many respondents in their relationship to Judaism. For most of them, Jewish identity essentially meant belonging to a persecuted group, being "children of the Holocaust". One of our respondents expressed it in the following way:

"Among surviving Jews, there is a kind of .. disunified ... but unconscious sympathy towards the person who -if not himself, then his parents-suifered through the same thing. You cannot ignore it, if, when you are speaking with someone, his shirtsleeve slides up and discloses a number tattooed on his arm. Among a person's close and distant acquaintances, there is certain to be someone who fell victim.. but 
even if everyone in the entire family survived the catastrophe, that too will have caused terrible damage. Of course, this ... is a kind of unifying force." of the Holocaust was still a major determining factor. The reduction of Jewish identity to the common experience of being victimized or being a child of victims signifies the fact that in the decades after the war there was practically no possibility for Jews in Hungary to work through the past: the public taboo contributed to the prolongation of private sufferings. This reduction was, on the other hand, part of another tendency: assimilation.

In our interviews, we attempted to explore sociological and historical dimensions, too, by asking our respondents to narrate the life histories of their family members going back to three generations. These life histories reveal typical assimilation strategies. Identity formulations themselves, based on the Holocaust and on the awareness of common sufferings worked, in many cases, as a special assimilation strategy. I mean here that someone can be perfectly unaware of the elements of Jewish religion or tradition or culture, someone might have no essential relationship to Judaism at all -but, at the same time, the person can assume that there is no need to rediscover such ties because being a child of survivors is sufficient by itself to make him or her belong to the Jewish group, in such a way and to such an extent as the person might wish it. In principle, then, someone can be good Hungarian, good Christian, good Communist etc. -being Jewish has nothing to do with the person's actual group affilations. In other words: for most of our respondents, being Jewish meant belonging to some kind of secondary or virtual community, based not so much on common interactions as on allusory identifications.

\section{The stategy of silence}

In the second layer of Hungarian Jewish identity we found what we called the "strategy of silence". While secondary traumatization means unconscious transmisson of the trauma suffered by the parents, the "strategy of silence" means a more or less conscious effort on the part of the parents to conceal the fact of their belonging to the once-persecuted group. Children growing up in these familles experienced an inconceivable family secret and were socialized in an environment where tradition had been more or less eliminated and the generational continuity of the family history broken. Analysis of the interview material within the context of the question, "How didyou come torealize that you are Jewish?" revealed that, for many respondents, even learning the fact of their being Jewish proved to be an extremely conflictual emotional experience. Often they had been "enlightened" by strangers, and, even when the "enlightenment" took place in the family, it was typically a reaction to a painful situation experienced by the child or adolescent outside the family. A respondent told us:

"At the age of 13, I didn't know what it meant to be Jewish, I didn't even know the word. This may sound strange, but at that time, when I first heard the word, it was not from them [the parents], but from a friend four years older than myself. He told me that we were Jews and all about what happened to the Jews. It was then that I leamt for the first time what happened to us, and I became very frightened, and ever since then I haven't been able to accept these facts. The truth of the matter is that I have never been able particularly willing to deal with it, beleiving, as a matter of principle, that if I close my eyes they cannot see me. In short, if I don't deal with the problem, then there won't be any, just there won't be any antisemitism". 


\section{Jews and communists}

14 The above quotation speaks for itself. If you don't speak about the problems, they don't exist, and, what is more important, if you close your eyes, they cannot see you. The strategy of silence and "closed eyes" was, first of all, characteristic of those families where the dominant ideology was Communism. "We were Communists, not Jewish". Our family had nothing to dowith Jews. It was only an accident that we were Jewish; we were Communists, andit was much more important. .. Webelonged to a larger family, and in relation to this, our being Jewish had no significance ... These and similar statements show the efforts of the parents to get rid of their Jewishness by accepting and enforcing the "universalistic" values of Communism. One of our respondents found -in his later years- the cadre file of his mother. In the cadre file she red the CV-s her father was forced to write in the early fifties. In each year the father wrote: "I have a four, five, six ... year old daughter. My greatest wish is to raise her so that she become a valuable member of oursocialist society. As these children were growning up, they were told: "If people ask you what your religion is, you should tell them that you have no religious affiliation". For children growing up in the fifties, this itself sometimes become the basis of discriminatation. For example, in contrast to the majority of their classmates, they celebrated not Christmas but the birthday of Comrade Stalin (21 December). It would be easy to argue that these parents refused to be Jewish because they strongly believed in Communist ideology. I think, however, that there were deeper and more complex motives. These motives are clearly stated by a sentence quoted by one of our respondents from his father who was a highranking functionary: "There is no God after Auschwitz. After all those things happened to us, there is no -there must be no God". If there is now God, there are no traditions; one has to break with everything which -even distantly- has associations with God. In this aspect, Communism was a radical refusal of religion, because it absolutely excludes the existence of God. Communism is a revenge against the God who allowed all this to happen. The same respondent told us the story:

"When I was a little child, I needed a circumcision for simple health reasons. The doctor said: he must be circumcised! But my parents did not consent to the operation. My father somehow procured some penicillin (it was very difficult in the fifties), and I was cured".

Then he related the following story: an uncle smuggled food to the ghetto in a Hungarian nazi (arrow-cross) uniform. He was caught, made to pull down his trousers, and beaten almost to death. This narrative explains clearly the deeper, non-rational motive of affiliating to Communism. It was depression, the emptiness of the self. "My father... -our respondent told us- ...did not existinside ... After Auschwitz there was no inside, as there isno Jewish life. This is our tragedy, and this will be the tragedy of our children -the inhibition of the internal ide family life. In certain sense, this made the family dead ... Because we were in the selection process, if there had been any family life, any inside solidarity, it should have been Jewish. But who wanted it?"

\section{Breaking the silence}

Is it the end of the story? In a certain way, it was only the beginning. The next layer is what I would call the "breaking the silence". For many respondents these interviews were 
the first occasion that they could speak about this topic in a more or less systematic way. We asked them to tell us many family legends, stories, childhood memories (even the most insignificant ones) as they could remember. "Justtell everything occurs to your mind in relation to this topic!". So we could observe the narrative construction of Jewish identity, the process by which identity was created through telling "stories". These stories were full of pictures of a lost world, second-hand memories, incomprehensible words which were, for the first time, put together into a systematic narrative. In this way, the process of reconstruction of the continuity of the family history may have been begun.

To be sure, most of the identity-relevant statements were formulations of a marginal identity. To be Jewish means a vague feeling of being different, but the terms in which these differences are measured are not always clear. The majority of our respondents stated that most of their friends as well as their partners were Jewish, without their having consciously sought out Jewish contacts only. But, in any case, the discovery of whether another person is Jewish or not is basically a meta-communicative experience, as it is very difficult to formulate the criteria verbally by which a person's affiliation can be as certained.

This is the ideological side of identity: the ideological elaboration of group differences: what it means to be Jewish. It is the elaboration of group differences, that is, the way of finding out in what way Jews and non-Jews differ from each other. Most of our respondents worked out highly personalized criteria for this: e.g. they often described Jews as being more emotional, family-loving, more intelligent, possessing a greater sense of self-irony and humor, drinking less alcohol etc. On the other hand, we also encountered highly intellectualized ideologies concerning the role of Jews played in Hungarian or European history and culture.

Beyond the ideological formulations, there is another aspect of identity that we may call "interactional identity". It is an identity model according to which the person manifests his or her self in actual social situations which can be sometimes conflictual and tense. According to our experience, "being Jewish" in concrete situations is a "borderline" problem. This means that Jewish identity may come up only as a reaction to an extreme situation: for example, if one becomes target of antisemitic statements or attacks. "Basically, I am not Jewish; but if I meet anantisemite, I become Jewish" -this is the typical formulation of a reactive, marginal, "borderline" Jewish identity manifested in conrete interactions.

\section{Beyond identity crisis}

20 In our interviews, however, we discovered the beginnings of another kind of Jewish identity, that is a positive relation to Judaism, the recognition that "being Jewish" means not only humiliation, suffering, psychological disturbance or discrimination. The development of a positive identity comes after "breaking the silence". This creates a new situation. When "being Jewish" appears primarily as an intrapsychic, emotional problem, there are no open conflicts. After "breaking the silence", however, one has to choose and manifest one's identity in public situations, too. The previous regime, the KDR-era, when our interviews were made, was the world of "private deals" between citizens and the state. The problem of "being Jewish" was, in a way, an "underground" problem, Jewish identity existed as a marginal identity. The open, public manifestation of identity was blocked out by a series of political and social obstacles. However, already in the eighties, 
some of our interviewees started to reflect on the question: which of the existing models of Jewish identity they should accept? Religious, traditional, cultural, ethnie, national models and their combinations already emerged as possible models of Jewish identity. In our days, the problem of Jewish identity seem to be acquiring new aspects. On the one hand, new and public manifestations of antisemitism or "neoantisemitism" arouses the feeling of being Jewish even in some of those people, who, until now, tried to avoid the problem by applying the "strategy of silence". On the other, the new antisemitic propaganda evokes new fears and anxieties. In general, however, it is hoped that the emerging new, autonomous civil society will give the full possibility for renewal of Jewish identity and commitment to this identity without any external and internal constraint. It is difficult to predict what models and forms of Jewish identity will be dominant -or will, can any of these be dominant? It seems to me that it is not possible to prescribe any uniquely valid identity model. The plurality of identity models can really be developed only after "breaking the silence", that is, only in a process in the course of which the elements of social and individual pathology gradually lose their significance. This development also presupposes that there are no social and political situations where certain categories of identity are forcefully exiled to the margin. In this aspect, the question of Jewish identity is a question of democracy -as all questions of minority identity pertain to democracy, all over the world.

\section{NOTES}

1. This paper is an edited version of the author's paper presented at the Seminar on "Identity Renewal: Studies in Eastern European Jewish Life Histories", Tel-Aviv University. School of Education. 6-10 October. 1991. A Hungarian version of the text was published in a volume edited by Mâria M. Kovacs, Yitzhak Kashti and Ferenc Eros: Zsidosag, identitas, torténelem, T-Twins, Budapest, 1992, pp. 85-96. Author's address: Institute of Psychology of the Hungarian Academy of Sciences, Teréz krt. 13, H-1394 Budapest, Hungary.

2. See the following reports on this research: Ferenc Eros - Andras Kovacs - Katalin Lévai: "Hogyan jottem ra, hogy zsidô vagyok?" Interj?k ("How 1 came to realize that 1 was Jewish?" Interviews.) "Medvetanc, 1985/2-3., pp. 129-144. This text was published in French: "Comment j'en suis arrivé a apprendre que je suis Juif?" Actes de la recherche en sCiencessociales, no. 56., mars 1985, pp. 62-68., and in German: "Wie ich schliesslich gemerkt habe, dass ich Jude bin?" Interviews mit ungarischen Juden aus der Nachkrieggeneration. Babylon, Beitrage zur jüdischen Gegenwart. Heft 3, 1988, pp. 65-79. See furthermore: Ferenc Eros - Andras Kovacs: The biographical method in the study of Jewish identity. In: T. Hofer - P. Niedermüller (eds.): Life History as Cultural Cosntruction/Performance. Budapest, 1988, pp. 345-356. See also Andras Kovacs s contribution to the present volume.

3. See e.g. Teréz Virag: Children of the Holocaust and their Children's Children: Working through CUITent trauma in the psychotherapeutic process. Dynamic Psychotherapy. Vol. 2. No. 1.Spring-Summer 1984, 47- 60.

4. See e.g. Martin S. Bergman - Milton E. Jucovy (eds.): Generations of the Holocaust, Basic Books, New York 1982. 


\section{RÉSUMÉS}

L'article analyse certains aspects de l'identité hongroise juive dans les années 1980. Cet article se base sur un projet de recherche sur l'identité juive élaboré essentiellement à partir d'une série d'histoires de la vie de personnes appartenant à la "seconde génération", c'est-à-dire dont les parents avaient survécu à l'Holocauste. Sur la base de ces entretiens, l'article aborde des questions primordiales telles que la transmission d'expériences traumatisantes à la génération suivante, la stratégie du silence, les principales caractéristiques des processus de socialisation dans des familles juives à l'époque du Communisme, et, enfin, il soulève la question des différentes alternatives pour l'identité juive moderne.

INDEX

Mots-clés : identité, Hongrie, juifs, mémoire, transmission, holocauste

Keywords : identity, Hungary, jews, memory, holocaust

\section{AUTEUR}

\section{DR. FERENC EROS}

Institut de psychologie, Budapest 